\title{
GFP-tagged multimetal-tolerant bacteria and their detection in the rhizosphere of white mustard
}

\author{
Zofia Piotrowska-Seget • Grażyna Beściak • \\ Tytus Bernaś • Jacek Kozdrój
}

Received: 27 September 2010 / Accepted: 1 June 2011 /Published online: 17 June 2011

(C) The Author(s) 2011. This article is published with open access at Springerlink.com

\begin{abstract}
The introduction of rhizobacteria that tolerate heavy metals is a promising approach to support plants involved in phytoextraction and phytostabilisation. In this study, soil of a metal-mine wasteland was analyzed for the presence of metal-tolerant bacterial isolates, and the tolerance patterns of the isolated strains for a number of heavy metals and antibiotics were compared. Several of the multimetal-tolerant strains were tagged with a broad host range reporter plasmid (i.e. pPROBE-NT) bearing a green fluorescent protein marker gene $(g f p)$. Overall, the metaltolerant isolates were predominately Gram-negative bacteria. Most of the strains showed a tolerance to five metals $(\mathrm{Zn}, \mathrm{Cu}, \mathrm{Ni}, \mathrm{Pb}$ and $\mathrm{Cd}$ ), but with differing tolerance patterns. From among the successfully tagged isolates, we used the transconjugant Pseudomonas putida G25 (pPROBE-NT) to inoculate white mustard seedlings.
\end{abstract}

Z. Piotrowska-Seget

Department of Microbiology, University of Silesia,

Jagiellońska 28,

40-032 Katowice, Poland

G. Beściak

Department of Environmental Biotechnology,

Silesian University of Technology,

Akademicka 2,

44-100 Gliwice, Poland

T. Bernaś

Department of Physiology and Medical Physics,

Royal College of Surgeons in Ireland (RCSI),

123 St Stephens Green,

Dublin 2, Ireland

J. Kozdrój ( $\square)$

Department of Microbiology, University of Agriculture in Krakow,

Mickiewicza 24/28,

30-059 Kraków, Poland

e-mail: j.kozdroj@ur.krakow.pl
Despite a significant decrease in transconjugant abundance in the rhizosphere, the $g f p$-tagged cells survived on the root surfaces at a level previously reported for root colonisers.

Keywords Bacterial inoculation · GFP-tagged strains · Metal tolerance $\cdot$ Mine soil $\cdot$ Rhizosphere colonisation

\section{Introduction}

The introduction of rhizosphere-competent bacteria that are able to tolerate increased concentrations of heavy metals is a promising approach for the improvement of phytoextraction and phytostabilisation carried out by some metaltolerant plants (Kuiper et al. 2004; Lebeau et al. 2008). Plant inoculation with the released bacteria has to be accompanied with the monitoring of their survival in the rhizosphere. Therefore, inoculants should be tagged with a marker that allows the introduced cells to be identified and monitored among the populations of indigenous soil microorganisms. One of the more useful methods to do this relies on the $g f p$ gene, which encodes the green fluorescent protein (GFP) from the jellyfish Aequora victoria (Errampalli et al. 1999). The unique feature of this marker is its exclusive suitability for monitoring released bacteria in soils because the $g f p$ is absent in soil microorganisms, and the expression of green fluorescence does not require any substrate or cofactor (Unge et al. 1998; Cassidy et al. 2000; Kozdrój et al. 2004). In addition, the $g f p$ marker enables the researcher to study the introduced strains in situ with a minimum of sample preparation, thus avoiding possible disturbance of the natural cell colonisation pattern.

GFP-tagged bacteria have been used to inoculate the soil and the seeds/seedlings of plants exposed to high levels of 
heavy metals (Liao et al. 2006; Braud et al. 2009; Ma et al. 2009). The major goal of such studies is to identify the conditions affecting both the survival of the released mutants and their activity in terms of the stabilisation of metal concentrations in a habitat. Beneficial bacterial inoculants are selected to support the growth of plants; these generally show tolerance to heavy metals and have phytoextraction or phytostabilisation activity (Wu et al. 2006a; Braud et al. 2009). This results in the establishment of relevant plant-microorganism associations that are highly compatible in removing metal from soil (Lebeau et al. 2008). Metal-mine wastelands, which standardly contain high concentrations of heavy metals, such as zinc ( $\mathrm{Zn})$, copper $(\mathrm{Cu})$, lead $(\mathrm{Pb})$, nickel $(\mathrm{Ni})$, and cadmium $(\mathrm{Cd})$, can be rich sources of metal-resistant bacteria and metalresistant plants (Barrutia et al. 2011) for bioaugmentationassisted phytoextraction and phytostabilisation. For example, Ma et al. (2009) reported that the Cu-resistant strain of Achromobacter xylosoxidans significantly improved $\mathrm{Cu}$ uptake by metal-accumulating Indian mustard (Brassica juncea) and promoted plant growth. However, before any bacterial strain can be used for soil bioaugmentation-assisted phytoremediation, its survival, persistence and habitat colonisation, as well as its ability to interact with a plant host must be assessed.

White mustard (Sinapis alba) belongs to a diverse group of mustards that show an increased tolerance to heavy metals. These plants have been suggested for application in the phytoextraction or phytostabilisation of the metals in contaminated soils (Wu et al. 2006b; Lebeau et al. 2008). Reporter broad host range plasmids of the pPROBE series containing GFP gene have been employed to construct bacterial metal-biosensors (Liao et al. 2006) or inoculants used for bioaugmentation of a metal-contaminated soil (Braud et al. 2009). We report here the first trials to introduce these plasmids into multimetal-tolerant bacterial isolates from the soil of a metal-mine wasteland. The aim of the research was to determine which of the $g f p$-marked multimetal-tolerant bacterial strains were able to survive in the rhizosphere and on the roots of white mustard. These trials represent the first step to assess an application potential of the plant-bacteria association in a metalcontaminated environment.

\section{Materials and methods}

Source of metal-tolerant bacteria

A composite soil sample, prepared from eight different subsamples taken from an area of $25 \mathrm{~m}^{2}$, was collected from the top layer $(0-10 \mathrm{~cm})$ of a metal-mine wasteland in Piekary Slaskie. The site is located in Upper Silesia, an industrialised region of southern Poland. The soil $(\mathrm{pH} 7.04$, organic matter $2.6 \%$ ) contained high total concentrations of $\mathrm{Zn}, \mathrm{Pb}, \mathrm{Cu}, \mathrm{Cd}$ and $\mathrm{Ni}$ (i.e. $30,11,2.8,0.2$ and $0.09 \mathrm{mg} \mathrm{g}^{-1}$ dry soil, respectively). The concentrations were determined by atomic absorption spectrometry (UNICAM 939/959) after wet-mineralisation in a mixture of $\mathrm{HNO}_{3}(4 \mathrm{ml})$ and $\mathrm{H}_{2} \mathrm{O}_{2}(1 \mathrm{ml})$, using a microwave oven (Piotrowska-Seget et al. 2005).

To isolate metal-tolerant bacteria, triplicate soil samples $(10 \mathrm{~g})$ were placed in Erlenmeyer flasks, each containing $90 \mathrm{ml}$ of $0.1 \%$ sterile sodium pyrophosphate (pH 7.0), and shaken at $120 \mathrm{rpm}$ for $30 \mathrm{~min}$. Serial tenfold dilutions of these soil suspensions were plated onto one-tenth strength trypticase soy broth agar [0.1× TSBA: tryptic soy broth (TSB; Difco, Detroit, MI) $3 \mathrm{~g}$, agar $15 \mathrm{~g} \mathrm{l}^{-1}, \mathrm{pH}$ 7.0] and King's B agar (Bacto peptone $20 \mathrm{~g}, \mathrm{~K}_{2} \mathrm{HPO}_{4} 1.5 \mathrm{~g}$, $\mathrm{MgSO}_{4} \cdot 7 \mathrm{H}_{2} \mathrm{O} 1.5 \mathrm{~g}$, glycerol $10 \mathrm{ml}$, agar $15 \mathrm{~g}$, demineralised water $11, \mathrm{pH}$ 7.2) amended with $3 \mathrm{mM} \mathrm{Zn}$ (as chloride). The plates were incubated at $24^{\circ} \mathrm{C}$ for 5 days (Rasmussen and Sørensen 2001) followed by subculturing of representative colonies differing in morphology and colour onto fresh agar plates. Bacterial isolates were selected from the $10^{-3}$ and $10^{-4}$ dilutions. A total of 25 isolates were selected and used for identification, using Gram staining and analysis of cellular fatty acid methyl esters (FAMEs).

Identification of bacterial isolates and their tolerance patterns

We extracted FAMEs (MIDI Inc, Newark, DE) from each isolate, using the standard and recommended procedure that included saponification, derivatisation, extraction and final base washing (Microbial ID Inc. 1999). The organic phase, containing cellular FAMEs, was separated using a HP 6890 gas chromatograph (GC; Hewlett Packard, Palo Alto, CA) on a Ultra 2-HP capillary column with hydrogen as the carrier gas and analysed by Sherlock 4.0 MIDI software, using the aerobe TSBA40 method and TSBA40 library (MIDI Inc). The MIDI system generated a similarity index (SI) for each strain as a mark of the confidence with which the isolate was identified. Strains with an SI level $>0.3$ were considered to be identified (Germida and Siciliano 2001; Piotrowska-Seget et al. 2005).

We determined the metal tolerance pattern of each metaltolerant strain by the minimum inhibitory concentration (MIC) approach. To this end, $0.1 \times$ TSBA plates, amended with increasing (from 1 to $10 \mathrm{mM}$ ) levels of $\mathrm{Zn}, \mathrm{Cu}, \mathrm{Cd}, \mathrm{Ni}$ or $\mathrm{Pb}$, were inoculated with bacterial strains and incubated at $24^{\circ} \mathrm{C}$ for 3 days. The MIC was defined as the lowest metal concentration preventing the growth of the strains.

To establish an antibiotic tolerance of the isolated bacteria, each strain was plated onto $0.1 \times$ TSBA supple- 
mented with ampicillin (Ap; $\left.100 \mu \mathrm{g} \mathrm{ml}^{-1}\right)$, tetracycline (Tc; $20 \mu \mathrm{g} \mathrm{ml}^{-1}$ ) or kanamycin $\left(\mathrm{Km} ; 20 \mu \mathrm{g} \mathrm{ml}^{-1}\right.$ ) followed by incubation at $24^{\circ} \mathrm{C}$ for 3 days. The isolates growing on respective plates were considered to be antibiotic tolerant.

\section{Tagging with GFP of bacterial isolates}

Two different strains of Escherichia coli were used in a triparental conjugation to introduce $g f p$ into selected metaltolerant bacterial isolates. The promoter-probe strain of $E$. coli (pPROBE-NT), harbouring a PnptII::gfp fusion (Miller et al. 2000), was used as the source of a mobilisable plasmid, containing a red-shifted $g f p$ gene associated with a Km resistance gene. In addition, used E. coli (pRK2013) resistant to Km (Figurski and Helinski 1979) as the donor of a self-transmissible plasmid pRK2013 that mobilised pPROBE-NT to the recipient isolates.

The procedure of triparental mating consisted of three steps. First, 0.5-ml aliquots of E. coli (pPROBE-NT) (optical density at $560 \mathrm{~nm}$ : 0.6 ) were mixed with $0.5 \mathrm{ml}$ of $E$. coli (pRK2013) (optical density at $560 \mathrm{~nm}: 0.8$ ) and concentrated by centrifugation for $5 \mathrm{~min}$ at $2,700 \mathrm{~g}$. The bacterial pellet was then suspended in $0.5 \mathrm{ml}$ of sterile saline followed by the centrifugation for $1 \mathrm{~min}$ at $2,700 \mathrm{~g}$. Second, a 1-ml aliquot of a recipient isolate (optical density at $560 \mathrm{~nm}$ : 0.9) was added to the pellet, mixed and centrifuged for $1 \mathrm{~min}$ at $2,700 \mathrm{~g}$. The bacterial pellet was then suspended in $0.1 \mathrm{ml}$ of sterile saline followed by plating onto LB agar (Difco, $\mathrm{pH}$ 7.2). The inoculated plates were incubated at $37^{\circ} \mathrm{C}$ for $24 \mathrm{~h}$. Third, the transconjugant cultures were thoroughly scraped from the plates and suspended in $2 \mathrm{ml}$ of sterile saline. The suspensions were serially diluted up to $10^{-3}$ followed by plating $(0.1 \mathrm{ml})$ onto $0.1 \times$ TSBA supplemented with Ap $\left(100 \mu \mathrm{g} \mathrm{ml}^{-1}\right), \mathrm{Km}$ $\left(20 \mu \mathrm{g} \mathrm{ml}^{-1}\right)$ and $3 \mathrm{mM} \mathrm{Zn} \mathrm{(as} \mathrm{chloride).} \mathrm{As} \mathrm{transconjugant}$ controls, the cultures of donor or particular recipients (optical density at $560 \mathrm{~nm}$ : 0.8 ) were also spread on a similar medium amended with the antibiotics and the metal. All plates were incubated at $27^{\circ} \mathrm{C}$ for $24-48 \mathrm{~h}$ until distinct colonies were seen. Finally, we restreaked selected colonies on the selection plates to ensure purity and the presence of the markers. Putative transconjugant cells were checked for GFP expression under an Olympus FluoView FV1000 confocal laser scanning microscope (Olympus, Tokyo, Japan). The microscope was equipped with a multiline argon laser (excitation $488 \mathrm{~nm}$, emission range 500$550 \mathrm{~nm}$ ) and a water immersion (WI) planapochromatic $60 \times / 1.20$ objective.

Survival of GFP-transconjugants in the rhizosphere

For the survival studies, we chose GFP-tagged Pseudomonas putida G25 (pPROBE-NT) isolates that showed the best growth under the selection conditions as well strong and persistent expression of the $g f p$. To this end, we incubated the transconjugant culture overnight with shaking at $28^{\circ} \mathrm{C}$ until late log phase $\left(10^{9} \mathrm{CFU} \mathrm{ml}^{-1}\right)$, after which the cells were harvested by centrifugation and washed three times in sterile saline before being suspended in $10 \mathrm{ml}$ of the saline.

The soil of the metal-mine wasteland was air-dried to about $15 \%(\mathrm{w} / \mathrm{w})$ moisture content, sieved (mesh diameter $2 \mathrm{~mm})$, placed in plastic containers $(300 \mathrm{~g})$ and wetted with distilled water to about $35 \%(\mathrm{w} / \mathrm{w})$ moisture content. This moisture corresponded to about $50 \%(\mathrm{w} / \mathrm{w})$ of the water holding capacity of the soil. Prior to the trials, we seeded triplicate soil portions with white mustard (Sinapis arvensis). These were left for 3 weeks to grow in a plant growth cabinet under a light/dark regime $\left(26^{\circ} \mathrm{C}, 16 \mathrm{~h} / 21^{\circ} \mathrm{C}, 8 \mathrm{~h}\right)$ at a relative air humidity of $75 \%$. The tolerance of indigenous culturable bacteria to $\mathrm{Ap}, \mathrm{Tc}$ and $\mathrm{Km}$ was checked by plating serial dilutions of triplicated soil samples (3 g, shaken at $130 \mathrm{rpm}$ for $30 \mathrm{~min}$ ) onto $0.1 \times$ TSBA amended with Ap $\left(100 \mu \mathrm{g} \mathrm{ml}^{-1}\right)$, Tc $\left(20 \mu \mathrm{g} \mathrm{ml}^{-1}\right)$ or Km $\left(20 \mu \mathrm{g} \mathrm{ml}^{-1}\right)$ followed by incubation at $24^{\circ} \mathrm{C}$ for 6 days.

To inoculate mustard seedlings, we added a suspension of transconjugant $P$. putida $\mathrm{G} 25\left(\log 7.82 \mathrm{CFU} \mathrm{ml}^{-1}\right)$ to the soil surface, establishing a moisture content of about $35 \%$. All pots were placed in the plant growth cabinet under a light/dark regime $\left(26^{\circ} \mathrm{C}, 16 \mathrm{~h} / 21^{\circ} \mathrm{C}, 8 \mathrm{~h}\right)$ at a relative air humidity of $75 \%$.

After $0,7,14,28$ and 54 days, white mustard seedlings were carefully removed from the soil, and the roots with adhering rhizosphere soil were placed in sterile $0.1 \%$ sodium pyrophosphate ( $\mathrm{pH}$ 7.0) for shaking (130 rev $\mathrm{min}^{-1}, 30 \mathrm{~min}$ ) and preparing serial tenfold dilutions. Replicate aliquots from the rhizosphere dilutions were spread-plated onto $0.1 \times$ TSBA amended with either Ap $\left(100 \mu \mathrm{g} \mathrm{ml}^{-1}\right)$ or $\mathrm{Km}$ $\left(20 \mu \mathrm{g} \mathrm{ml}^{-1}\right.$ ) for the counting of $P$. putida $\mathrm{G} 25$ (pPROBENT). The medium without the antibiotics was used to enumerate total indigenous heterotrophic bacteria. The medium was also amended with cycloheximide $(\mathrm{Ch}$; $100 \mu \mathrm{g} \mathrm{ml}^{-1}$ ) to inhibit the growth of fungi. In addition, to avoid a possible masking effect of indigenous fluorescent Pseudomonas spp., we supplemented the selective medium with $0.45 \mathrm{mM} \mathrm{FeSO} \cdot 7 \mathrm{H}_{2} \mathrm{O}$, which represses siderophore biosynthesis (Timms-Wilson and Bailey 2001). Plates inoculated with the transconjugant $P$. putida $\mathrm{G} 25$ were analysed after incubation at $24^{\circ} \mathrm{C}$ for $2-4$ days, whereas those for the total heterotrophic bacteria were incubated for 6 days. We enumerated fluorescent colonies containing GFP using a hand-held UV light in a dark room.

Selected white mustard roots with adhering soil were collected for microscopic observations. To this end, the samples of roots and rhizosphere soil were separately transferred to glass vials containing $8 \mathrm{ml}$ of $0.1 \%$ sodium 
pyrophosphate $(\mathrm{pH}$ 7.0). The roots were gently washed for $30 \mathrm{~s}$, while the rhizosphere soil samples $(1 \mathrm{~g})$ were vigorously shaken for $5 \mathrm{~min}$. After the large soil particles had settled down $\left(15 \mathrm{~min}, 18^{\circ} \mathrm{C}\right)$, a drop of the upper level of the soil suspension was applied to a microscope slide. The slide was then prepared for observation under a confocal laser microscope (Unge et al. 1998). The root samples were washed three times in saline, and the excised fragments (maximum length: $10 \mathrm{~mm}$ ) were placed on microscope slides and prepared for observation under the confocal microscope.

\section{Statistics}

The count data of culturable bacteria were subjected to the analysis of variance (ANOVA) followed with post hoc comparison of means using Fisher's least significant difference test (LSD, $n=3, p<0.05$ ). To compare the patterns of tolerance to the metals and antibiotics among the isolated bacterial strains, we used a joining method of the cluster analysis (CA) module (Statistica ver 6.0; StatSoft, Tulsa, OK) and Ward's clustering algorithm. Thus, a dendrogram showing clustering trends among all isolates was created.

\section{Results and discussion}

Isolation of metal-tolerant strains from metalliferous soil

Soil of a metal-mine wasteland is a habitat rich in heavy metals that exert a strong selecting pressure that enables the growth of different metal-tolerant bacteria. Low concentrations of nutrients and the restricted availability of water and oxygen are additional constraints on the growth of microorganisms in this habitat. It has been reported that Gram-positive bacterial species predominate among the bacteria surviving in soils polluted with high concentrations of heavy metals (Roane and Kellog 1996; Ellis et al. 2003; Åkerblom et al. 2007; Sułowicz et al. 2011). By contrast, other studies have indicated that it is Gram-negative bacteria which predominate in sites rich in heavy metals (Kunito et al. 1997; Brim et al. 1999; Piotrowska-Seget et al. 2005). In total, we isolated $25 \mathrm{Cu}$-tolerant bacterial strains from the soil collected at the metal-mine wasteland; of these 16 isolates were Gram-negative and nine strains were Gram-positive organisms. With the exception of two isolates, IGB 2 and IGB 8, these metal-tolerant strains were identified to the species level based on their MIDI-FAME profiles, all with SI $>0.600$ (Table 1). The highest number (i.e. 10) of strains were identified as Pseudomonas putida. This species and other fluorescent pseudomonads have often been reported as organisms of great adaptability to harsh conditions in soil contaminated with heavy metals (Roane 1999; Duponnois et al. 2006; Wu et al. 2006a).

Most bacterial strains revealed tolerance to five metals; however, the tolerance patterns differed among the isolates. Three strains of Pantoea agglomerans expressed high tolerance to all the metals. In turn, Citrobacter diversus and Klebsiella pneumoniae were tolerant to 10 or $9 \mathrm{mM} \mathrm{Zn}$, and the latter strain was also resistant to $3 \mathrm{mM} \mathrm{Cd}$. In addition, the isolate IGB 8 tolerated up to $10 \mathrm{mM}$ of $\mathrm{Cu}$ and $\mathrm{Ni}$ (Table 1). Overall, most strains tolerated higher concentrations of $\mathrm{Zn}, \mathrm{Cu}$ and $\mathrm{Ni}$ than of $\mathrm{Pb}$ and $\mathrm{Cd}$. Similar results were obtained by Piotrowska-Seget et al. (2005) for metaltolerant bacteria isolated from polluted arable soils and barren spoil of a former silver mine. Multimetal tolerance is a characteristic feature of different heterotrophic bacteria isolated from highly polluted soils (Trojanovska et al. 1997; Malik et al. 2002; Sułowicz et al. 2011). Ryan et al. (2005) found that $82 \%$ of isolates from metal-polluted soil showed resistance to five out of eight tested metals. PiotrowskaSeget et al. (2005) also found that plasmid-containing bacteria were tolerant of several metals. Multimetal-tolerant bacterial strains have been found to be able to survive in metalliferous soils planted with some plants showing an increased tolerance to various metals (Epelde et al. 2010; Sułowicz et al. 2011).

In terms of antibiotic tolerance, only five of the identified species (i.e. Bacillus cereus GB1, Arthrobacter oxydans, Citrobacter diversus, Brevibacterium acetylicum and Pseudomonas putida G17) showed a tolerance to Tc, $\mathrm{Kn}$ and/or Ap. A similar number of strains, however, all belonging to one species, namely P. putida (i.e. G15, G16, G18, G24 and G25), tolerated only Ap. By contrast, four strains (i.e. Bacillus sphaericus GB3, B. cereus GB7, B. amyloliquefaciens and the isolate IGB 8 ) were sensitive to all three antibiotics (Table 1). Antibiotic tolerance often accompanies an increased resistance to heavy metals among different bacteria isolated from sites exposed to high pollution and/or containing material rich in the metals (Berg et al. 2005; Stepanauskas et al. 2005; Baker-Austin et al. 2006). This situation results from the co-transfer of antibiotic resistance genes and those of metal resistance on the same plasmid under selective conditions (Foster 1983; Baker-Austin et al. 2006). However, the ecological role of this association for bacterial strains occupying a severe habitat is not fully understood. Presumably, the extra feature of antibiotic resistance increases their survival success during the competition for available niches when in the presence of compounds acting as antimicrobials and signal molecules. As a result, respective strains of bacteria may differ in their tolerance profiles, which may in turn affect their survival (Alonso et al. 2001; Hibbing et al. 2010). Our cluster analysis of the metal and antibiotic tolerance patterns of all the bacterial strains showed that they grouped 
Table 1 Bacterial strains isolated from a metalliferous soil and their patterns of tolerance to selected heavy metals and antibiotics
${ }^{a}$ Minimum inhibitory concentrations were determined on $0.1 \times$ tryptic soy broth $($ TSA) amended with the metals

${ }^{\mathrm{b}}$ The strains are tolerant $(\mathrm{r})$ or sensitive (s) to: ampicillin (Ap; $\left.100 \mu \mathrm{g} \mathrm{ml}^{-1}\right)$, tetracycline $(\mathrm{Tc}$; $\left.20 \mu \mathrm{g} \mathrm{ml} \mathrm{m}^{-1}\right)$, kanamycin $(\mathrm{Km}$; $20 \mu \mathrm{g} \mathrm{ml}^{-1}$ )

\begin{tabular}{|c|c|c|c|c|c|c|c|c|}
\hline \multirow[t]{2}{*}{ Strain } & \multicolumn{5}{|c|}{$\mathrm{MIC}^{\mathrm{a}}(\mathrm{mM})$} & \multicolumn{3}{|c|}{ Antibiotics $^{\mathrm{b}}$} \\
\hline & $\mathrm{Zn}$ & $\mathrm{Cu}$ & $\mathrm{Ni}$ & $\mathrm{Pb}$ & $\mathrm{Cd}$ & Ap & $\mathrm{Tc}$ & $\mathrm{Km}$ \\
\hline Bacillus cereus GB1 & 7 & 5 & 6 & 2 & 1 & $\mathrm{r}$ & $\mathrm{r}$ & $\mathrm{r}$ \\
\hline Isolate GB2 & 7 & 6 & 5 & 2 & 1 & $\mathrm{r}$ & $\mathrm{s}$ & $\mathrm{r}$ \\
\hline Bacillus sphaericus GB3 & 4 & 6 & 3 & 2 & 0 & s & s & $\mathrm{s}$ \\
\hline Arthrobacter oxydans & 6 & 6 & 4 & 2 & 1 & $\mathrm{r}$ & $\mathrm{r}$ & $\mathrm{r}$ \\
\hline Citrobacter diversus & 10 & 7 & 7 & 1 & 2 & $\mathrm{r}$ & $\mathrm{r}$ & $\mathrm{r}$ \\
\hline Klebsiella pneumoniae & 9 & 8 & 7 & 2 & 3 & $\mathrm{r}$ & $\mathrm{r}$ & $\mathrm{s}$ \\
\hline Bacillus cereus GB7 & 8 & 6 & 4 & 3 & 0 & s & $\mathrm{s}$ & $\mathrm{s}$ \\
\hline Isolate GB8 & 8 & 10 & 10 & 3 & 0 & $\mathrm{~s}$ & $\mathrm{~s}$ & $\mathrm{~s}$ \\
\hline Brevibacterium acetylicum & 5 & 5 & 6 & 3 & 2 & $\mathrm{r}$ & $\mathrm{r}$ & $\mathrm{r}$ \\
\hline Bacillus sphaericus GB10 & 5 & 7 & 6 & 2 & 1 & $\mathrm{~s}$ & $\mathrm{~s}$ & $\mathrm{r}$ \\
\hline Bacillus amyloliquefaciens & 6 & 8 & 7 & 2 & 1 & $\mathrm{~s}$ & $\mathrm{~s}$ & $\mathrm{~s}$ \\
\hline Pantoea agglomerans GP12 & 9 & 10 & 6 & 2 & 4 & $\mathrm{r}$ & $\mathrm{s}$ & $\mathrm{r}$ \\
\hline Pantoea agglomerans GP13 & 9 & 10 & 6 & 2 & 3 & $\mathrm{r}$ & $\mathrm{s}$ & $\mathrm{r}$ \\
\hline Pantoea agglomerans GP14 & 9 & 10 & 6 & 2 & 4 & $\mathrm{r}$ & $\mathrm{s}$ & $\mathrm{s}$ \\
\hline Pseudomonas putida G15 & 8 & 4 & 2 & 2 & 2 & $\mathrm{r}$ & $\mathrm{s}$ & $\mathrm{s}$ \\
\hline P. putida $\mathrm{G} 16$ & 7 & 4 & 4 & 2 & 2 & $\mathrm{r}$ & $\mathrm{s}$ & $\mathrm{s}$ \\
\hline P. putida G17 & 8 & 4 & 4 & 2 & 2 & $\mathrm{r}$ & $\mathrm{r}$ & $\mathrm{r}$ \\
\hline P. putida G18 & 0 & 2 & 2 & 1 & 2 & $\mathrm{r}$ & $\mathrm{s}$ & $\mathrm{s}$ \\
\hline P. putida $\mathrm{G} 19$ & 8 & 4 & 4 & 2 & 2 & $\mathrm{r}$ & $\mathrm{s}$ & s \\
\hline P. putida $\mathrm{G} 20$ & 8 & 4 & 4 & 2 & 2 & $\mathrm{r}$ & $\mathrm{s}$ & $\mathrm{r}$ \\
\hline P. putida $\mathrm{G} 21$ & 4 & 3 & 4 & 1 & 2 & $\mathrm{r}$ & $\mathrm{s}$ & $\mathrm{r}$ \\
\hline P. putida $\mathrm{G} 22$ & 7 & 3 & 4 & 3 & 2 & $\mathrm{r}$ & $\mathrm{s}$ & $\mathrm{r}$ \\
\hline Comamonas acidovorans & 7 & 3 & 4 & 3 & 1 & $\mathrm{r}$ & $\mathrm{s}$ & $\mathrm{r}$ \\
\hline P. putida $\mathrm{G} 24$ & 4 & 2 & 2 & 0 & 1 & $\mathrm{r}$ & $\mathrm{s}$ & $\mathrm{s}$ \\
\hline P. putida $\mathrm{G} 25$ & 7 & 3 & 2 & 2 & 1 & $\mathrm{r}$ & $\mathrm{s}$ & $\mathrm{s}$ \\
\hline
\end{tabular}

into two major clusters (Fig. 1). The first composite cluster included only strains of Pseudomonas putida, with the one exception being Comamonas acidovorans. However, the second major cluster was composed of two subclusters, with one comprising all of the Gram-positive strains, and the second consisting of Gram-negative strains of Pantoea agglomerans (clustering together) and Klebsiella pneumoniae grouping with Citrobacter diversus separately (Fig. 1). This clustering pattern shows that the separation of the $P$. putida group may have been associated with the possession of a common mechanism(s) of metal tolerance that is chromosomally encoded (Cánovas et al. 2003). In contrast, the Gram-positive strains with their thicker cell envelopes react to biocides differently. Their clustering might be, at least in part, due to the presence of a common plasmid carrying genes for multimetal and drug resistance (KamalaKanan and Kui Jae 2008). Bacterial species such as $P$. agglomerans, $K$. pneumoniae and $C$. diversus belong to the same family of Enterobacteriaceae. Therefore, they formed the separate cluster towards the other Gram-negative group of $P$. putida in this study. In addition, their likeness supports the fact the multidrug resistance (mar) operon is widespread

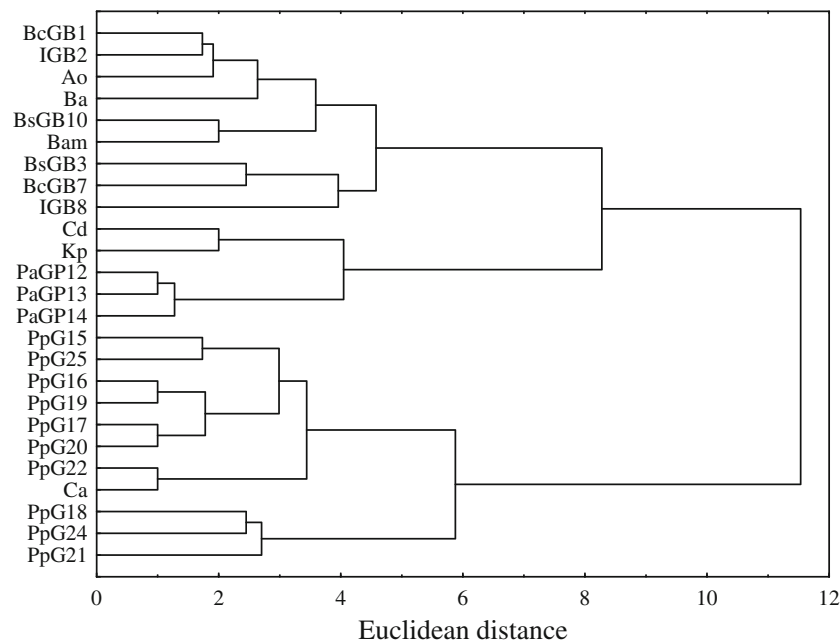

Fig. 1 Dendrogram representing similarities of metal and antibiotic tolerance patterns of different bacterial strains isolated from soil of a metal-mine wasteland. Ao Arthrobacter oxydans, Ba Brevibacterium acetylicum, Bam Bacillus amyloliquefaciens, Bc Bacillus cereus, Bs Bacillus sphaericus, Ca Comamonas acidovorans, Cd Citrobacter diversus, IGB2, IGB8 isolates GB2 and GB8, Kp Klebsiella pneumoniae, Pa Pantoea agglomerans, Pp Pseudomonas putida 
among enteric bacteria (Cohen et al. 1993). However, closer clustering of these bacteria with the Gram-positive group may be explained by their similar ability for protection against the biocides, due to the role of the cell envelopes (i.e. glycocalyx and thick cell wall, respectively). Regarding the cluster of $K$. pneumoniae and $C$. diversus, their likeness may have resulted from the presence of the same phosphatasemediated metal accumulation process involved in the detoxification of the bacteria (Macaskie et al. 1994).

$g f p$-tagged strains and its survival in the mustard rhizosphere

The underlying rationale for isolating metal-tolerant bacteria from metalliferous soils is their potential application for bioaugmentation-assisted phytoremediation of these habitats. Various markers, often with different detection frequencies, have been used to track the fates of these metal-tolerant bacterial isolates following their reintroduction into the soil (Zaidi et al. 2006; Ma et al. 2009). In our study, we successfully introduced the plasmid pPROBE-NT by triparental conjugation into four strains: Pseudomonas putida G16, P. putida G20, P. putida G25 and Comamonas acidovorans. The growth of these strains on selective agar medium containing Ap $\left(100 \mu \mathrm{g} \mathrm{ml}^{-1}\right), \mathrm{Km}\left(20 \mu \mathrm{g} \mathrm{ml}^{-1}\right)$ and $3 \mathrm{mM} \mathrm{Zn}$ was used to select for the pPROBE-NT transconjugants as neither donor strains nor recipients were able to grow on the medium amended with these markers. We also checked the putative transconjugants for GFP production under the confocal microscope. All transconjugants gave positive results, with $P$. putida G25 (pPROBE-NT) showing the strongest green colour, indicating intensive synthesis of the protein (Fig. 2). Therefore, we used transconjugant strain G25 for further survival experiments. An approach that involves the tagging of bacterial strains with $g f p$ genes by plasmid transfer or recombination into the chromosome has been recommended by various authors because of the efficient detectability of the tag and the low energetic burden placed on the cells. (Kendall and Badminton 1998; Errampalli et al. 1999; Kozdrój et al. 2004).

The introduction of metal-tolerant bacterial strains into soil seeded with plants that tolerate increased concentrations of heavy metals has been reported as a promising approach that facilitates the survival and development of these plants in contaminated habitats (Abou-Shanab et al. 2003; Sheng and Xia 2006; Ma et al. 2009). However, the success of this approach is dependent on the potential of the inoculant to colonise plant roots efficiently, which in turn is related to its own survival in the rhizosphere. To estimate the level of adaptation between the released inoculant cells and white mustard, we inoculated plant seedlings growing in a sandy soil. The numbers of $g f p$-tagged Pseudomonas putida $\mathrm{G} 25$ colonising the roots of white mustard decreased

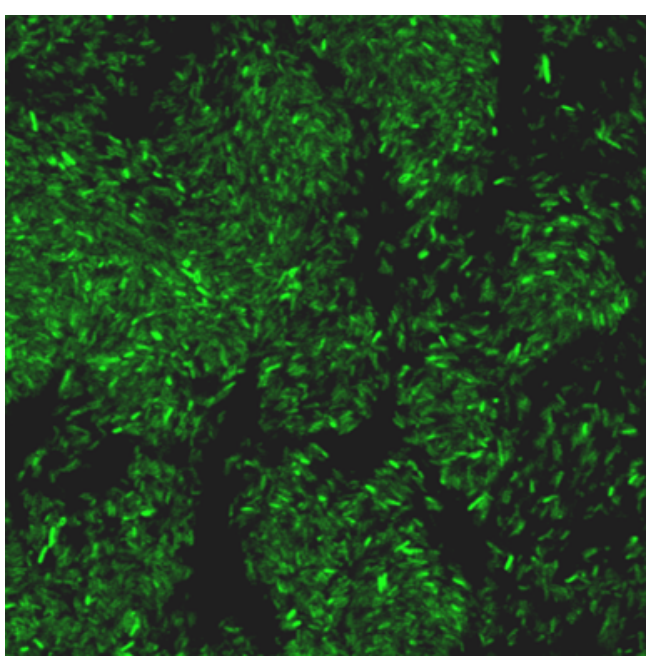

Fig. 2 Photograph of microscopic image of fluorescent green fluorescent protein $(g f p)$-tagged transconjugant Pseudomonas putida G25. The photograph was obtained using a confocal laser scanning microscope

from the initial $\log 7.48 \pm 0.28$ to $\log 4.95 \pm 0.25$ and $\log$ $3.62 \pm 0.18 \mathrm{CFU} \mathrm{g}^{-1}$ dry soil on days 14 and 54 postinoculation, respectively. The average counts of the total indigenous heterotrophic bacteria were about $\log 7.95 \pm$ $0.24 \mathrm{CFU} \mathrm{g}^{-1}$ dry soil in the rhizosphere. However, the natural resistance to $\mathrm{Ap}, \mathrm{Tc}$ and $\mathrm{Km}$ among the indigenous bacteria was below the detection limit of $\log 1.47 \pm$ $0.15 \mathrm{CFU} \mathrm{g}{ }^{-1}$ dry soil. The microscopic observation of root and rhizosphere preparations confirmed the successful survival of the transconjugant in the rhizosphere and the colonisation of the roots of white mustard seedlings on day 7 (Fig. 3). Although the presence of the $g f p$-tagged transconjugants on the roots was still visible on day 54, only a few bacterial cells were noticeable in the rhizosphere specimen (Fig. 4). A decrease in counts of introduced bacteria over a few days is often observed due to competition for nutrients and space with other rhizosphere microorganisms. They are grazed on by protozoa and exposed to abiotic stress; some cells die or lose culturability following release (van Veen et al. 1997). As a result, the inoculant population ultimately reaches a level reflecting its ability to adapt to conditions prevailing in the rhizosphere of the appropriate plant species (de Weger et al. 1995; Kozdrój et al. 2004). Errampalli et al. (1998) indicated that gfp-marked Pseudomonas sp., introduced into a creosotecontaminated soil, declined over a 26-day period, although the low numbers recovered up to 13 months after inoculation. It can also not be excluded that the decreased numbers of $P$. putida G25 (pPROBE-NT) may have resulted from the loss of the plasmid over time. However, this vector has been reported to be a stable one in a broad range of bacterial hosts (Miller et al. 2000). Belimov et al. (2004) reported a slight decrease in the numbers of inoculant 

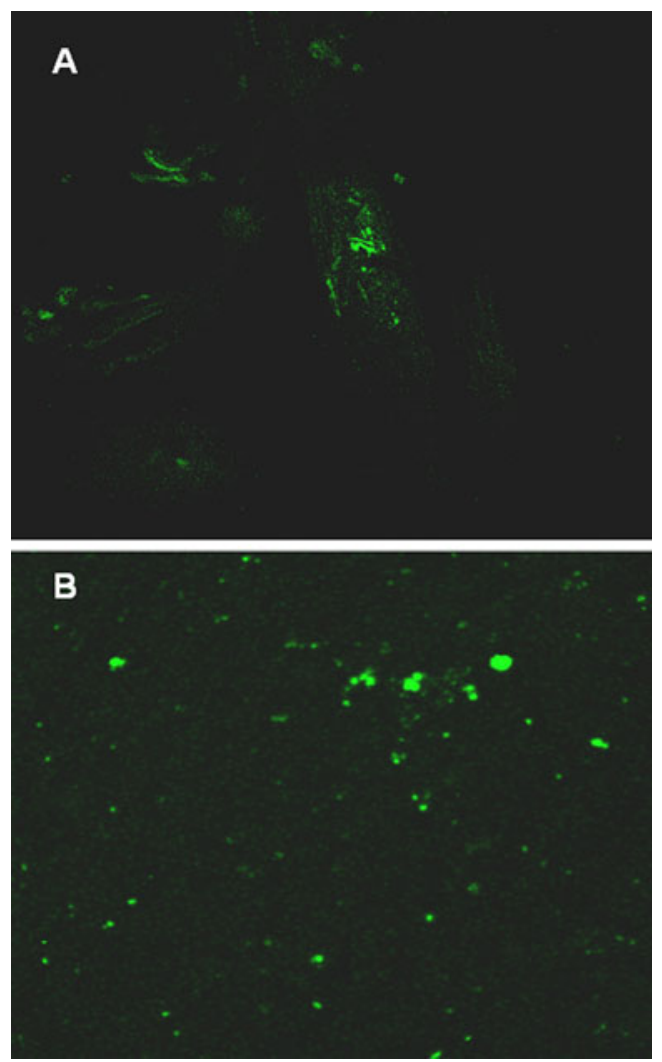

Fig. 3 Photographs of microscopic images of fluorescent $g f p$-tagged transconjugant Pseudomonas putida G25 colonising the root surface of a 7-day-old seedling of white mustard (a) and those surviving in the rhizosphere (b). The photographs were obtained with a confocal laser scanning microscope

rhizobacteria between days 10 and 25 during their colonisation of barley roots. By contrast, an introduced population of Bacillus sp. that was resistant to Cd was still detectable at the same density in the rhizosphere of rape 2 weeks after inoculation (Sheng and Xia 2006). In addition, the survival of inoculants associated with a plant host depends on changes in the physiological state of the plant (Lebeau et al. 2008). Wu et al. (2006b) reported that young mustard seedlings are more favourable to an introduced metal-tolerant strain than flowering plants, possibly due to differences in the composition of the root exudates. We obtained similar results for the survival of $g f p$-tagged $P$. putida G25. Immobilisation of bacterial inoculants into carriers, such as alginate, clay, peat or methyl cellulose, which protects them against biotic and abiotic environmental stress, can increase both their survival in soil as well as their colonisation of soil (van Veen et al. 1997; Kozdrój et al. 2004; Braud et al. 2009). However, to facilitate colonisation of the entire rhizosphere and roots of growing seedlings by the released bacterial strains, the application of free-cell suspensions, instead of immobilised cells, appears to be useful (Ciccillo et al. 2002; Mazolla et al. 1995).
In conclusion, the soil of the metal-mine wasteland is a habitat favouring the selection of multimetal-tolerant heterotrophic bacteria, mostly represented by Gramnegative species, which can be differentiated according to their metal and antibiotic tolerance patterns. Although these bacteria are characterised by their high metal tolerance, only a few strains can be recipients of the $g f p$-bearing reporter plasmid and subsequently express the green fluorescent protein. Indeed, one recipient strain, Pseudomonas putida $\mathrm{G} 25$, yielded a transconjugant that distinctly expressed GFP and was able to colonise the rhizosphere and roots of white mustard seedlings. Despite a significant decrease in the counts of the transconjugant in the rhizosphere, the $g f p$-tagged cells persist at the level reported for root colonisers (Scher et al. 1994). This result is a promising indicator of plant-transconjugant interdependence that can favour both partners. Further studies are needed to determine whether P. putida G25 (pPROBE-NT) can promote the growth of white mustard in soil containing high concentrations of heavy metals, bearing in mind that the ultimate goal is the potential application of both organisms in bioaugmentation-assisted phytoremediation of polluted habitats.
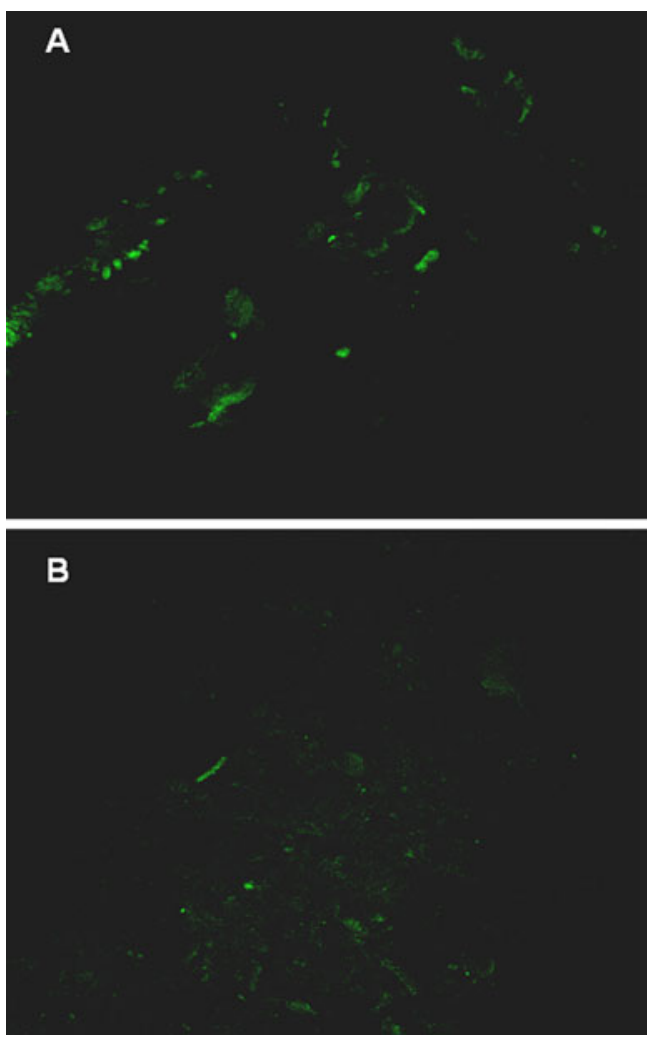

Fig. 4 Photographs of microscopic images of fluorescent $g f p$-tagged transconjugant $P$. putida $\mathrm{G} 25$ colonising the root surface of a 54-dayold seedling of white mustard (a) and those surviving in the rhizosphere (b). The photographs were obtained with a confocal laser scanning microscope 
Open Access This article is distributed under the terms of the Creative Commons Attribution Noncommercial License which permits any noncommercial use, distribution, and reproduction in any medium, provided the original author(s) and source are credited.

\section{References}

Abou-Shanab RA, Angle JS, Delorme TA, Chaney RL, van Berkum P, Moawad H, Ghanem K, Ghozlan HA (2003) Rhizobacterial effects on nickel extraction from soil and uptake by Alyssum murale. New Phytol 158:219-224

Åkerblom S, Bååth E, Bringmark L, Bringmark E (2007) Experimentally induced effects of heavy metal on microbial activity and community structure of forest mor layers. Biol Fertil Soils 44:79-91

Alonso A, Sánchez P, Martínez JL (2001) Environmental selection of antibiotic resistance genes. Environ Microbiol 3:1-9

Baker-Austin C, Wright MS, Stepanauskas R, McArthur JV (2006) Co-selection of antibiotic and metal resistance. Trends Microbiol 14:176-182

Barrutia O, Artetxe U, Hernández A, Olano JM, García-Plazaola JI, Garbisu C, Becerril JM (2011) Native plant community growing on an abandoned lead-zinc mining area in northern Spain: implications for phytoremediation and germplasm preservation. Int J Phytoremediat 13:256-270

Belimov AA, Kunakova AM, Safronova VI, Stepanok VV, Yudkin LY, Alekseev YV, Kozhemyakov AP (2004) Employment of rhizobacteria for the inoculation of barley plants cultivated in soil contaminated with lead and cadmium. Microbiology 73:99-106

Berg J, Tom-Petersen A, Nybroe O (2005) Copper amendment of agricultural soil selects for bacterial antibiotic resistance in the field. Lett Appl Microbiol 40:146-151

Braud A, Jézéquel K, Bazot S, Lebeau T (2009) Enhanced phytoextraction of an agricultural $\mathrm{Cr}$ - and $\mathrm{Pb}$-contaminated soil by bioaugmentation with siderophore-producing bacteria. Chemosphere 74:280-286

Brim H, Heuer H, Krögerrecklenfort E, Mergeay M, Smalla K (1999) Characterization of the bacterial community of a zinc-polluted soil. Can J Microbiol 45:326-338

Cánovas D, Cases I, de Lorenzo V (2003) Heavy metal tolerance and metal homeostasis in Pseudomonas putida as revealed by complete genome analysis. Environ Microbiol 5:1242-1256

Cassidy MB, Leung KT, Lee H, Trevors JT (2000) A comparison of enumeration methods for culturable Pseudomonas fluorescens cells marked with green fluorescent protein. J Microbiol Methods 40:135-145

Ciccillo F, Fiore A, Bevivino A, Dalmastri C, Tabacchioni S, Chiarini L (2002) Effects of two different application methods of Burkholderia ambifaria MCI 7 on plant growth and rhizospheric bacterial diversity. Environ Microbiol 4:238-245

Cohen SP, Yan W, Levy SB (1993) A multidrug resistance regulatory chromosomal locus is widespread among enteric bacteria. J Infect Dis 168:484-489

De Weger LA, van der Bij AJ, Dekkers LC, Simons M, Wijffelman CA, Lugtenberg BJJ (1995) Colonization of the rhizosphere of crop plants by plant-beneficial pseudomonads. FEMS Microbiol Ecol 17:221-228

Duponnois R, Kisa M, Assigbetse K, Prin Y, Thioulouse J, Issartel M, Moulin P, Lepage M (2006) Fluorescent pseudomonads occurring in Macrotermes subhyalinus mound structures decrease $\mathrm{Cd}$ toxicity and improve its accumulation in sorghum plants. Sci Total Environ 370:391-400

Ellis RJ, Morgan P, Weightman AJ, Fry JC (2003) Cultivationdependent and -independent approaches for determining bacterial diversity in heavy-metal-contaminated soil. Appl Environ Microbiol 69:223-3230

Epelde L, Becerril JM, Barrutia O, González-Oreja JA, Garbisu C (2010) Interactions between plant and rhizosphere microbial communities in a metalliferous soil. Environ Pollut 158:15761583

Errampalli D, Okamura H, Lee H, Trevors JD, van Elsas JD (1998) Green fluorescent protein as a marker to monitor survival of phenanthrene-mineralizing Pseudomonas sp. UG14Gr in creosote-contaminated soil. FEMS Microbiol Ecol 26:181-191

Errampalli D, Leung K, Cassidy MB, Kostrzynska M, Blears M, Lee H, Trevors JT (1999) Applications of the green fluorescent protein as a molecular marker in environmental microorganisms. J Microbiol Methods 35:187-199

Figurski DH, Helinski DR (1979) Replication of origin-containing derivative of plasmid RK2 dependent on a plasmid function provided in trans. Proc Natl Acad Sci USA 76:1648-1652

Foster TJ (1983) Plasmid-determined resistance to antimicrobial drugs and toxic metal ions in bacteria. Microbiol Rev 47:361409

Germida JJ, Siciliano SD (2001) Taxonomic diversity of bacteria associated with the roots of modern, recent and ancient wheat cultivars. Biol Fertil Soils 33:410-415

Hibbing ME, Faqua C, Parsek MR, Peterson SB (2010) Bacterial competition: surviving and thriving in the microbial jungle. Nat Rev Microbiol 8:15-25

Kamala-Kanan S, Kui Jae L (2008) Metal tolerance and antibiotic resistance of Bacillus species isolated from Sunchon Bay sediments, South Korea. Biotechnology 7:149-152

Kendall JM, Badminton N (1998) Aquorea victoria bioluminescence moves into an exciting new era. TIBTECH 16:216-224

Kozdrój J, Trevors JT, van Elsas JD (2004) Influence of introduced potential biocontrol agents on maize seedling growth and bacterial community structure in the rhizosphere. Soil Biol Biochem 36:1775-1784

Kuiper I, Lagendijk EL, Bloemberg GV, Lugtenberg BJJ (2004) Rhizoremediation: a beneficial plant-microbe interaction. Mol Plant-Microb Interact 17:6-15

Kunito T, Shibata S, Matsumoto S, Oyaizu H (1997) Zinc resistance of Methylobacterium species. Biosci Biotechnol Biochem 61:729731

Lebeau T, Braud A, Jézéquel K (2008) Performance of bioaugmentationassisted phytoextraction applied to metal contaminated soils: A review. Environ Pollut 153:497-522

Liao VH-Ch, Chien M-T, Tseng Y-Y, Ou K-L (2006) Assessment of heavy metal bioavailability in contaminated sediments and soils using green fluorescent protein-based bacterial biosensors. Environ Pollut 142:17-23

Ma Y, Rajkumar M, Freitas H (2009) Inoculation of plant growth promoting bacterium Achromobacter xylosoxidans strain Ax10 for the improvement of copper phytoextraction by Brassica juncea. J Environ Manag 90:831-837

Macaskie LE, Bonthrone KM, Rouch DA (1994) Phosphatasemediated heavy metal accumulation by a Citrobacter sp. and related enterobacteria. FEMS Microbiol Lett 121:141-146

Malik A, Khan IF, Aleem A (2002). Plasmid incidence in bacteria from agricultural and industrial soils. World J Microbiol Biotechnol 18:827-833

Mazolla M, Stahlman PW, Leach JE (1995) Application method affects the distribution and efficacy of rhizobacteria suppressive of downy brome (Bromus tectorum). Soil Biol Biochem 27:1271-1278

Microbial ID Inc. (1999) Microbial identification system operating manual, version 7. Microbial ID Inc, Newark 
Miller WG, Leveau JHJ, Lindow SE (2000) Improved $g f p$ and inaZ broad-host-range promoter-probe vectors. Mol Plant-Microb Interact 13:1243-1250

Piotrowska-Seget Z, Cycoń M, Kozdrój J (2005) Metal-tolerant bacteria occurring in heavily polluted soil and mine spoil. Appl Soil Ecol 28:237-246

Rasmussen LD, Sørensen SJ (2001) Effects of mercury contamination on the culturable heterotrophic, functional and genetic diversity of the bacterial community in soil. FEMS Microbiol Ecol 36:1-9

Roane TM (1999) Lead resistance in two bacterial isolates from heavy metal-contaminated soils. Microb Ecol 37:218-224

Roane TM, Kellog ST (1996) Characterization of bacterial communities in heavy metal contaminated soils. Can J Microbiol 42:593-603

Ryan R, Ryan D, Dowling D (2005) Multiple metal resistant transferable phenotypes in bacteria as indicators of soil contamination with heavy metals. J Soil Sediment 5:95-100

Scher FM, Ziegle JS, Kloepper JW (1994) A method for assessing the root-colonizing capacity of bacteria on maize. Can J Microbiol $30: 151-157$

Sheng XF, Xia JJ (2006) Improvement of rape (Brassica napus) plant growth and cadmium uptake by cadmium-resistant bacteria. Chemosphere 64:1036-1042

Stepanauskas R, Glenn TC, Jagoe CH, Tuckfield RC, Lindell AH, McArthur JV (2005) Elevated microbial tolerance to metals and antibiotics in metal-contaminated industrial environments. Environ Sci Technol 39:3671-3678
Sułowicz S, Płociniczak T, Piotrowska-Seget Z, Kozdrój J (2011) Significance of silver birch and bushgrass for establishment of microbial heterotrophic community in a metal-mine spoil heap. Water Air Soil Pollut 214:205-218

Timms-Wilson TM, Bailey MJ (2001) Reliable use of green fluorescent protein in fluorescent pseudomonads. J Microbiol Methods 46:77-80

Trojanovska S, Brotz ML, Bhave M (1997) Detection of heavy metal ion resistance genes in Gram-positive and Gram-negative bacteria isolated from a lead-contaminated site. Biodegradation $8: 113-124$

Unge A, Tombolini R, Davey ME, deBruijn FJ, Jansson JK (1998) GFP as a marker gene. In: de Bruijn FJ, van Elsas JD, Akkermans ADL (eds) Molecular microbial ecology manual. Kluwer, Dordrecht, pp 1-16, 6.1.13

Van Veen JA, van Overbeek LS, van Elsas JD (1997) Fate and activity of microorganisms introduced into soil. Microbiol Mol Biol Rev 61:121-135

Wu CH, Wood TK, Mulchandani A, Chen W (2006a) Engineering plant-microbe symbiosis for rhizoremediation of heavy metals. Appl Environ Microbiol 72:1129-1134

Wu SC, Cheung KC, Luo YM, Wong MH (2006b) Effects of inoculation of plant growth-promoting rhizobacteria on metal uptake by Brassica juncea. Environ Pollut 140:124-135

Zaidi S, Usmani S, Singh BR, Musarrat J (2006) Significance of Bacillus subtilis strain SJ-101 as a bioinoculant for concurrent plant growth promotion and nickel accumulation in Brassica juncea. Chemosphere 64:991-997 